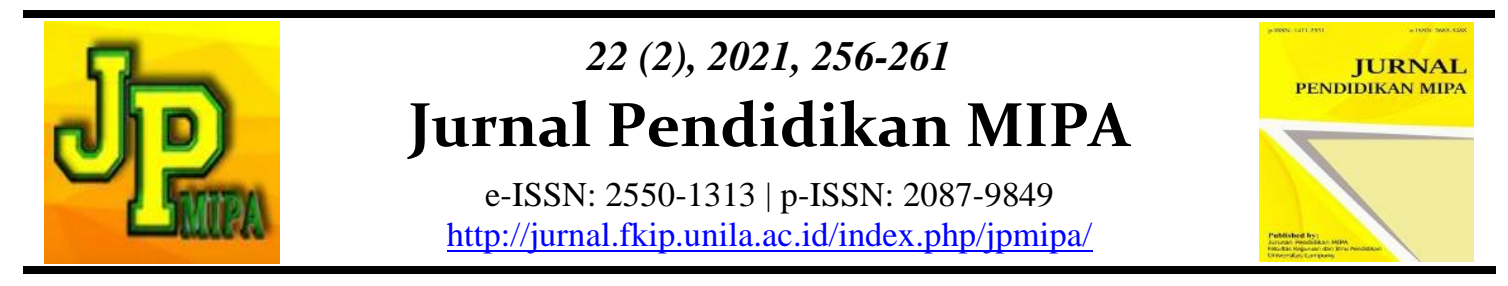

\title{
Online Learning Satisfaction Analysis of the Faculty of Computer Science Using the Fuzzy Logic Method
}

\author{
Yogi Ersan Fadrial ${ }^{1}$, Ambiyar $^{2}$, Fadhilah $^{2}$, Syahril $^{1}$, Rizki Novendra ${ }^{1}$, Sutejo $^{1}$ \\ ${ }^{1}$ Department of Computer Science, Universitas Lancang Kuning, Indonesia \\ ${ }^{2}$ Department of Technology and Vocational Education Universitas Negeri Padang, Indonesia
}

\begin{abstract}
Online learning is learning that uses the internet network with accessibility, connectivity, flexibility, and the ability to bring up various types of learning interactions. Satisfaction is a person's feelings of pleasure or disappointment that arise after comparing his perceptions of the performance or results of a product and his expectations. Research on student perceptions of online learning is limited to aspects of teaching and learning, the ability of lecturers, facilities and infrastructure. To get results from the perception or opinion of a student from the level of satisfaction of online lectures, it can be done using the Mamdani Fuzzy logic method and for calculations using the Slovin formula.
\end{abstract}

Keywords: technology, fuzzy logic, online learning, model.

Abstrak: Belajar online merupakan pembelajaran yang menggunakan jaringan internet dengan aksesibilitas, konektivitas, fleksibilitas, dan kemampuan untuk memunculkan berbagai jenis interaksi pembelajaran. Kepuasan merupakan perasaan senang atau kecewa seseorang yang muncul setelah membandingkan antara persepsi terhadap kinerja atau hasil suatu produk dan harapan-harapannya. Penelitian persepsi mahasiswa terhadap pembelajaran daring dibatasi pada aspek belajar mengajar, kemampuan Dosen, sarana dan prasarana. Untuk mendapatkan hasil dari persepsi atau pendapat seorang mahasiswa dari tingkat kepuasan perkuliahan online dapat dilakukan dengan menggunakan metode Fuzzy logic mamdani dan untuk perhitungan menggunakan rumus Slovin.

Kata kunci: teknologi, fuzzy logic, pembelajaran online, model.

\section{- INTRODUCTION}

The COVID-19 pandemic in Indonesia has had a negative impact on the world of education. One of them is through a circular message from the department of learning and culture (Kemendikbud) of the directorate of learning Number 1 of 2020 regarding the prevention of the spread of the corona virus at major academies, Lancang Kuning University swiftly responded to these instructions, which issued a circular message about vigilance and prevention. the spread of Covid-19 inflammation in the campus area. Analysis is a procedure for finding solutions to existing system cases by grouping smaller components so that the solutions found match the needs of the system (Bentley \& Whitten, 2009). Variables are all things in the form of anything that is authorized by researchers to be studied so that data is obtained about the subject, after which it is finally drawn. The variables to be used in this research are Tangible, Reliability, Responsiveness, Assurance, Empathy variables (Sugiyono, 2009).

Yogi Ersan Fadrial et al.

Email: yogiersan@unilak.ac.id
DOI: http://dx.doi.org/10.23960/jpmipa/v22i2.pp256-261

Received: 17 November 2021

Accepted: 22 December 2021 
Fuzzy logic that can explain each condition or represent human thoughts, the membership of elements lies in the interval $(0,1)$. Fuzzy logic is an alternative to various systems available for decision making, where the fuzzy set A in the U semester set can be expressed by an ordered set of X elements and their membership values. Matlab is one type of application that is used to manipulate matrices, implement algorithms, create user interfaces with programs that use various programming languages. Matlab or matrix laboratory was created in the 1970s by Cleve Moler who was chair of the department of computer science at the University of New Mexico. In 2004, MathWorks conducted a survey and found that Matlab has been used by more than one million users in education and industry. This research is limited to aspects of teaching and learning, Lecturer expertise, facilities and infrastructure. To get results from the opinions or comments of a student from the level of satisfaction of online lectures, you can try using the Mamdani Fuzzy logic method and make calculations using the Slovin formula.

\section{- METHOD}

This research was conducted by observation to identify the problem as a whole by means of a survey at the Faculty of Computer Science, Lancang Kuning University. Surveys and interviews, researchers then identify and formulate problems. How to analyze the level of student satisfaction with online lectures and whether online lectures are able to increase the effectiveness of the teaching and learning process between lecturers and students. The method used in this research is the fuzzy logic method and the Matlab application. The total number of students is 320 people. The data used in this study are primary data and secondary data, with data collection techniques literature studies and questionnaires.

Fuzzy logic is a system that is built based on rules in the form of a set of if-then rules. The advantages of using fuzzy logic are: fuzzy logic has a concept that is easy to understand, have tolerance for inaccurate data, able to model very complex non-linear data, can cooperate with other control techniques. Applying the experiences of experts directly without having to go through the training process.

The researcher uses the Slovin formula to determine the number of samples that will be the research target. The formula used is.

$$
\begin{aligned}
& n=\frac{N}{1+N\left(e^{2}\right)} \\
& \text { Information: } \\
& \mathrm{n} \quad: \text { number of samples } \\
& \mathrm{N} \quad: \text { population } \\
& \mathrm{e} \quad: \text { fault tolerance limit }(0.05)
\end{aligned}
$$

Researchers also determine the variables and domains of the fuzzy set to be able to determine the assessment that must be given to the respondents. The variables and domains of the fuzzy set include:

Tabel 1. Research variable

\begin{tabular}{ccc}
\hline Function Name & Variabel & Universe of Conversation \\
\hline \multirow{3}{*}{ Input } & Tangibles & {$[0-100]$} \\
\cline { 2 - 3 } & Responsiveness & {$[0-100]$} \\
\cline { 2 - 3 } & Reliability & {$[0-100]$}
\end{tabular}




\begin{tabular}{ccc} 
& Empati & {$[0-100]$} \\
\cline { 2 - 3 } & Assurance & {$[0-100]$} \\
\hline Output & Student Satisfaction Level & {$[0-100]$} \\
\hline
\end{tabular}

\section{- RESULT AND DISCUSSION}

This study was conducted to determine the level of student satisfaction with online lectures at the Faculty of Computer Science, Lancang Kuning University. In this study, the method used to assist the researcher in achieving the desired results is the Mamdani Fuzzy Logic method. The assessment variables used in this study are tangibles, responsiveness, reliability, empathy and assurance. After the data collection process was carried out, the population in this study was 320 people and the number of samples obtained after using the Slovin formula was 178 people, so the questionnaire model on Google Form was made in the form or linear scale model using 4 different answer choices consists of Strongly Disagree, Disagree, Agree, Strongly Agree.

In order to be able to present the variables in this study, it is divided into several parts:

a.

b.
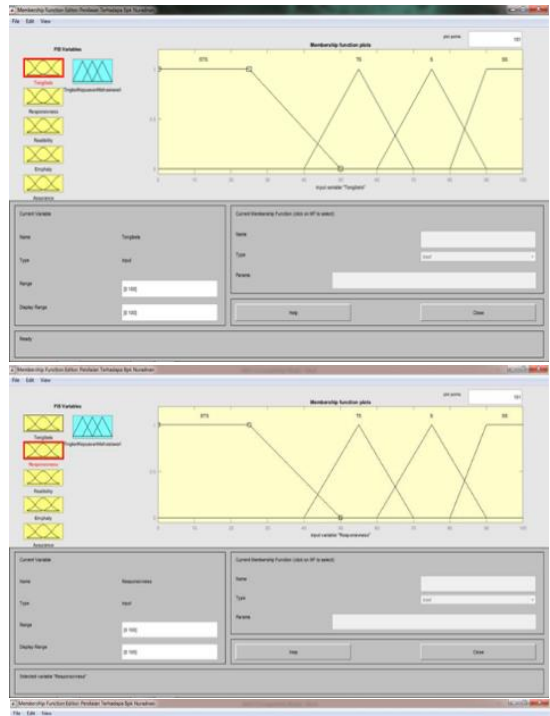

c.

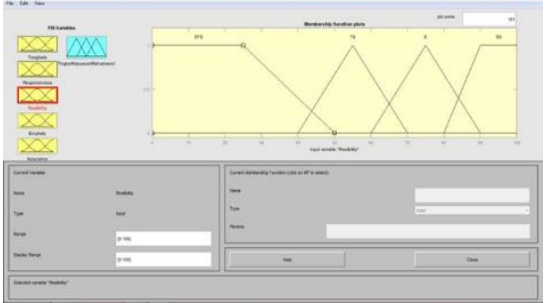

d.

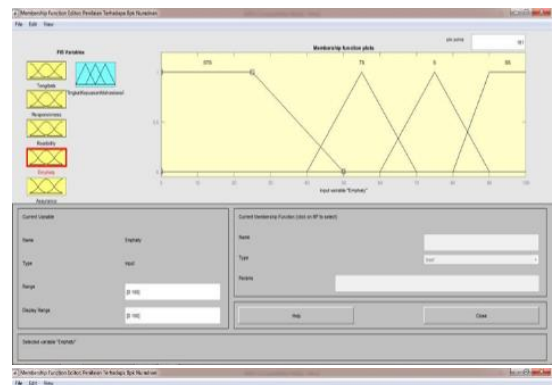

e.

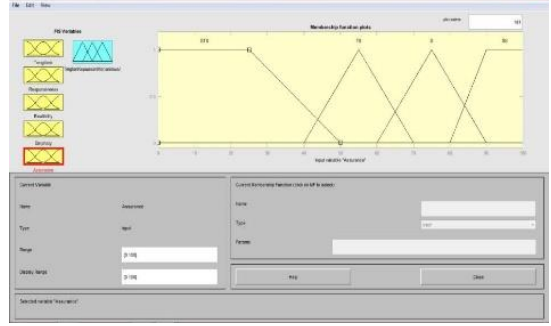

Figure 1. (a) - (e) Representation variable tangibles, responsiveness, reliability, emphaty, assurance.

To get the results of the desired rules, the data that has been obtained must be entered into the Matlab rules. The input process can be seen as shown below: 


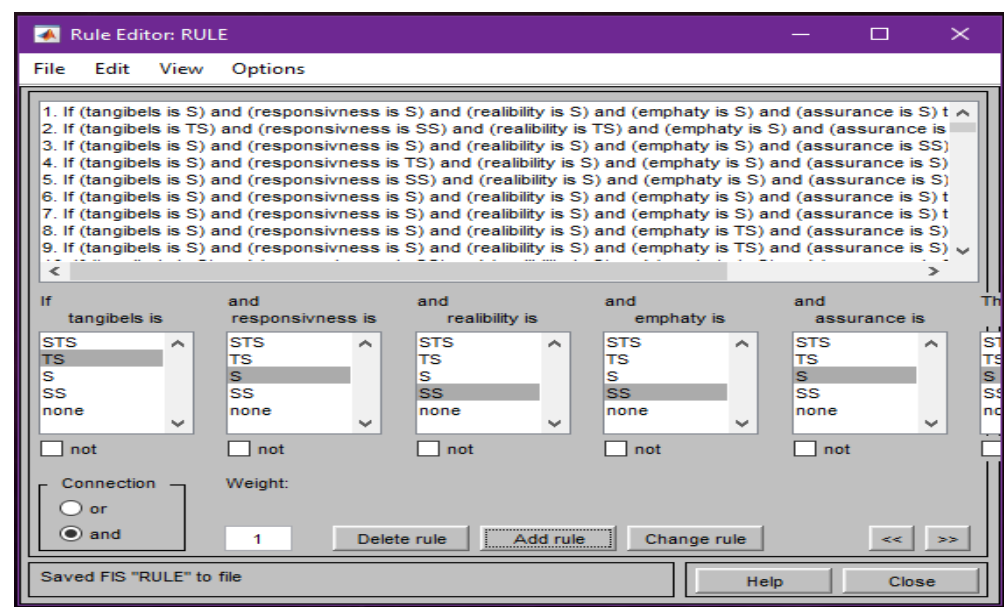

Figure 2. Input rules

After the process of inputting the rules as above, the researcher can see the results of the rules, as shown below:

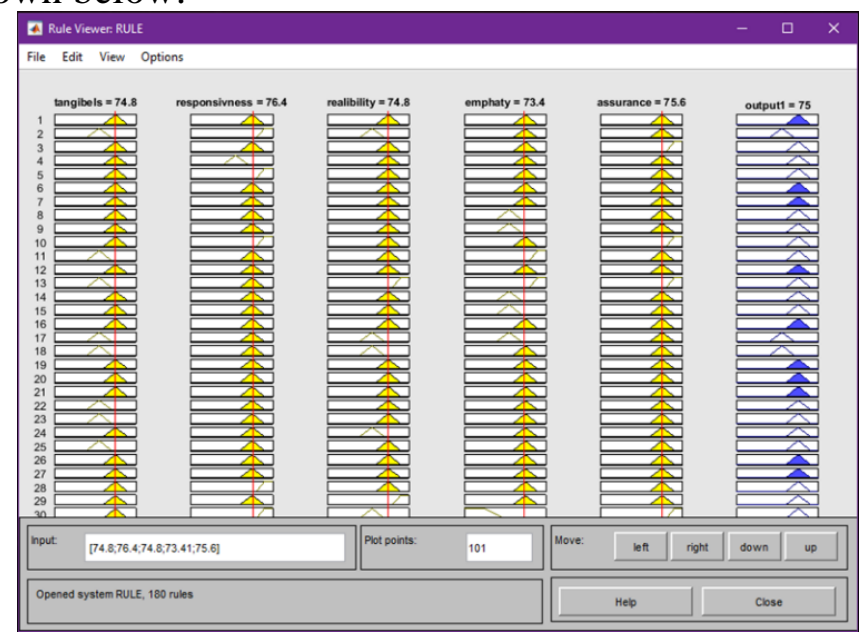

Figure 3. Results rules

The real number input is 74.8 which is a member of the fuzzy set domain "Agree [60-90]", the Responsiveness category gets a real number of 76.4 which is the fuzzy set domain "Agree [60-90]", the Reliability category gets a real number result of 74.8 which is the domain of the fuzzy set "Agree[60-90]". While Empathy gets a real number of 73.4 which is the domain of the fuzzy set "Agree [60-90]" and for the Assurance category it gets a real number of 75.6 which is the domain of the fuzzy set "Agree [60-90]". Therefore, it can be concluded that the statement consisting of these 5 variables, respondents "agree" with the statements in the questionnaire form they filled out.

The output of student satisfaction with online lectures in the era of the covid-19 pandemic is at number 75 which is the domain membership of the fuzzy number set "Satisfied [60-90]". This means that the variable level of student satisfaction with online lectures can be said to be Satisfied.

\section{- CONCLUSION}

Based on the results of data analysis and processing that has been carried out using the Fuzzy Logic method, it can be concluded that the process of measuring the level of satisfaction using the Mamdani fuzzy logic method and using the Matlab application can 
simplify and speed up researchers in managing research data with the analysis process carried out by researchers on the level of student satisfaction with online lectures, it can be concluded that the level of student satisfaction is in the real number 75 which is included in the satisfied category.

\section{- REFERENCES}

Zhang, Y., \& Lin, C. H. (2020). Student interaction and the role of the teacher in a state virtual high school: what predicts online learning satisfaction?. Technology, Pedagogy and Education, 29(1), 57-71.

Basith, A., Rosmaiyadi, R., Triani, S. N., \& Fitri, F. (2020). Investigation of Online Learning Satisfaction During COVID 19: In Relation to Academic Achievement. Journal of Educational Science and Technology (EST), 6(3), 265275.

Smaldino, Sharon E, dkk ( 2019). Instructional Technology \& Media For Learning.Pearson Education. Inc.

Yu, J., \& Couldry, N. (2020). Education as a domain of natural data extraction: analysing corporate discourse about educational tracking. Information, Communication \& Society, 1-18.

Bentley dan Whitten., (2009:160), System Analysis and Design For The Global Enterprise.

Yani, J. A. Sugiyono. 2017. Metode Penelitian Kuantitatif, Kualitatif, Dan R\&D [Quantitative Research Methods, And R\&D] Bandung: Alfabeta. Ferrari, JR, Jhonson, JL, \& McCown, WG (1995). Procrastination And Task Avoidance: Theory, Research \& Treatment. New York: Plenum Press. Yudistira P, Chandra. Diktat Kuliah Psikometri. Fakultas Psikologi Universitas.:

Teo, T., \& Wong, S. L. (2013). Modeling key drivers of e-learning satisfaction among student teachers. Journal of educational computing research, 48(1), 71-95.

González-Gómez, F., Guardiola, J., Rodríguez, Ó. M., \& Alonso, M. Á. M. (2012). Gender differences in e-learning satisfaction. Computers \& Education, 58(1), 283290.

Shen, D., Cho, M. H., Tsai, C. L., \& Marra, R. (2013). Unpacking online learning experiences: Online learning self-efficacy and learning satisfaction. The Internet and Higher Education, 19, 10-17.

Shin, W. S., \& Kang, M. (2015). The use of a mobile learning management system at an online university and its effect on learning satisfaction and achievement. International Review of Research in Open and Distributed Learning, 16(3), 110-130.

Dotulong, L. O., Kawet, L., \& Maukar, F. J. The Effect of Reliability, Responsiveness, Assurance, Empathy, and Tangibles to Sales Increase at PT. J. co Donuts \& Coffee Manado. Jurnal Riset Ekonomi, Manajemen, Bisnis dan Akuntansi, 3(2), 2579.

Prakoso, A. F., Nurul, R., Wulandari, A., Trisnawati, N., Fitrayati, D., Rachmawati, L., \& Andriansyah, E. H. (2017). Reliability, Responsiveness, Assurance, Empathy, and Tangible: Still Can Satisfy The Customer. International Journal of Business and Management Invention, 6(3), 68-75.

Fida, B. A., Ahmed, U., Al-Balushi, Y., \& Singh, D. (2020). Impact of service quality on customer loyalty and customer satisfaction in islamic banks in the Sultanate of Oman. Sage Open, 10(2), 2158244020919517. 
Asghar, M. Z., Subhan, F., Ahmad, H., Khan, W. Z., Hakak, S., Gadekallu, T. R., \& Alazab, M. (2021). Senti-eSystem: A sentiment-based eSystem-using hybridized fuzzy and deep neural network for measuring customer satisfaction. Software: Practice and Experience, 51(3), 571-594.

Troussas, C., Chrysafiadi, K., \& Virvou, M. (2019). An intelligent adaptive fuzzy-based inference system for computer-assisted language learning. Expert Systems with Applications, 127, 85-96.

Nilashi, M., Mardani, A., Liao, H., Ahmadi, H., Manaf, A. A., \& Almukadi, W. (2019). A hybrid method with TOPSIS and machine learning techniques for sustainable development of green hotels considering online reviews. Sustainability, 11(21), 6013.

Wan, S., \& Niu, Z. (2019). A hybrid e-learning recommendation approach based on learners' influence propagation. IEEE Transactions on Knowledge and Data Engineering, 32(5), 827-840.

Touat, M., Bouzidi-Hassini, S., Benbouzid-Sitayeb, F., \& Benhamou, B. (2017). A hybridization of genetic algorithms and fuzzy logic for the single-machine scheduling with flexible maintenance problem under human resource constraints. Applied Soft Computing, 59, 556-573.

Lalaoui, M., El Afia, A., \& Chiheb, R. (2018, May). Simulated annealing with adaptive neighborhood using fuzzy logic controller. In Proceedings of the International Conference on Learning and Optimization Algorithms: Theory and Applications (pp. 1-6).

Eyoh, I., John, R., \& De Maere, G. (2017). Interval type-2 A-intuitionistic fuzzy logic for regression problems. IEEE Transactions on Fuzzy Systems, 26(4), 2396-2408.

Carolina, I., Supriyatna, A., \& Puspitasari, D. (2020, July). Analisa Tingkat Kepuasan Mahasiswa Terhadap Perkuliahan Daring Pada Era Pandemi Covid 19 [Analysis of Student Satisfaction Levels with Online Lectures in the Covid-19 Pandemic Era] In Prosiding Seminar Nasional Riset Information Science (SENARIS) (Vol. 2, pp. 342-347).

Prasetya, T. A., \& Harjanto, C. T. (2020). Pengaruh mutu pembelajaran online dan tingkat kepuasan mahasiswa terhadap hasil belajar saat pandemi Covid19 [The influence of the quality of online learning and the level of student satisfaction on learning outcomes during the Covid19 pandemic]Jurnal Pendidikan Teknologi dan Kejuruan, 17(2), 188-197. 